\title{
PROBLÉM ŽÁNROVÉHO ZATRIEDENIA POSTMODERNISTICKEJ PRÓZY Z ASPEKTU INTERTEXTUALITY (NA PRÍKLADE PRÓZY VÍŤAZOSLAVA HRONCA) ${ }^{1}$
}

Protichodné procesy v genologickom definovaní žánrov postmodernistickej prózy prejavujú sa i na príklade Hroncovej knihy próz Pán vzduchu a králov syn. Intertextualita, ktorá sa prejavuje cez množstvo citácií rozmanitej typológie (od interliterárnych po transemiotické citáty a autocitáty) spôsobuje žánrovú hybridizáciu a znemožňuje obsiahnutie knihy do jednotného žánrového celku. Zároveň, v uvedenej Hroncovej knihe sa prostredníctvom intertextuality prejavuje i tendencia súdržnosti, ktorá sa reflektuje do žánrovej problematiky. Tak Hroncova kniha tvorí súbor poviedok, ktoré zároveň utvárajú vyšší súdržný celok. Ten celok nemožno nazvat' románom, lebo sa jeho hranice prostredníctvom autocitátcií rozpúšt’ajú smerom $\mathrm{k}$ lyrike. Akákol'vek snaha o definíciu žánru v prípade Hroncovej knižky Pán vzduchu a král'ov syn má aporický výsledok.

Kl'účové slová: literárny žáner, genológia, postmodernizmus, intertextualita, citát, poviedka, román, Vít’azoslav Hronec

Problém žánrového zatriedenia postmodernistickej prózy vzniká z istého napätia medzi dvomi protichodnými procesmi odvíjajúcimi sa vnútri samotnej postmodernistickej literatúry. Na jednej strane, postmodernistické dielo prejavuje vitálnu tendenciu po jednote, stabilite, zatial' čo v ňom prebieha neprestajné rozrušovanie, destabilizácia a fragmentárnost' na druhej strane. Výchadzajúc z danej situácie postmodernistickej literatúry, genologické výskumy prebiehajú v snahe uchopit' a pomenovat' uvedené protichodné procesy. $V$ metakomunikačnom diškurze to znamená uchopovanie tých procesov, ktoré zachovávajú stabilitu žánrov stanovenú v modernej literárnej vede, ako aj tých, ktoré žánrovú ukotvenost' a zatriedenost' neprestajne rozrušujú. Pri procese pomenúvania a definovania žánrov v literárnom postmodernizme teoretikovia zatial' narábajú s rovnakými pojmami ako pri žánroch minulých literárno-umeleckých období. Ich zvláštnost' a inovačnost' zatial' naznačujú priliehavými kompozitami „anti-žáner“, „travestia

marinasimak.spevakova@gmail.com

Príspevok je súčastou vedecko-výskumného projektu číslo 178017, ktorý podporuje Ministerstvo osvety, vedy a technologického rozvoja Republiky Srbsko. 
žánru“, „hybridizácia žánrových konvencií“, „,neobmedzená polyžánrovost”“ alebo jednoducho postmodernistická poviedka, postmodernistický román.

Problematike žánrov postmodernistickej literatúry v slovenskej literárnej vede náležitú pozornost' venovali Jozef Hvišč (1990), Tibor Žilka (1995) a Viliam Marčok (2010). Názory všetkých troch sa zhodujú v tvrdení, že v prípade žánrov v postmodernizme ide o dekompozíciu existujúcich žánrových útvarov. Podla Marčoka, žánrové tvarovanie textov môžeme sledovat' len od diela $\mathrm{k}$ dielu a jediná spoločná platforma na vnímanie genologickej problematiky je nastolenie otázky či ide o anti-žáner, alebo o rozpúštanie druhových a žánrových hraníc v prospech „žánru/žánrov“ (Marčok, 2010, 208).

Jedným z dôležitých faktorov dekompozície postmodernistického prozaického žánru je intertextualita. Intertextualitu v literárnom diele môžeme vnímat' ako výslednicu onej situácie subjektu, v ktorej nedokáže udržat' svoju výpoved' ,pod kontrolou“, v súradniciach dopredu zvoleného diškurzu. Neudržatel'nost' textu $\mathrm{v}$ dôsledku nátlaku iných textov spôsobuje neprestajné rozširovanie a prenikanie textu do rozličných poznávacích, ale aj žánrových sfér. Na úrovni metakomunikácie, intertextualita spôsobuje hybridizáciu, žánrové rozvrstvovanie, prelínanie a nejednotnost'. V štúdii sa sústredíme na aspekty rozrušovania žánru poviedok v knihe Pán vzduchu a králov syn Vítazoslava Hronca pod vplyvom intertextuality. Sústredíme sa však aj na tie prejavy v texte poviedok, ktoré nad’alej rešpektujú zásady žánrovej diferenciácie, aké rozoznávala moderná literárna veda. Pokúsime sa tiež odpovedat' na vyššie nastolenú dilemu, či v prípade uvedenej knižky ide o anti-žáner, alebo ,žáner/žánrov“.

Pri žánrovom zatried’ovaní knihy Pán vzduchu a králov syn (ktorú Harpáň, Dudok, Svetlík, Sulík, Glovňová a väčšina kritikov a recenzentov v časopisoch na Slovensku a v časopise Nový život definovala ako knihu poviedok) vychádzame $\mathrm{z}$ postmodernistických teórií pre intertextuálnu povahu jej textov. Texty v uvedenej knihe majú vlastnosti koláže, ktorú utvárajú žánrovo rozličné zložky a ich metatextový charakter. Ak v predchádzajúcich novelách existoval zárodok narúšania logiky a kauzálnosti (striedaním rôznych časových pásem vo vnútornom monológu, do toho vsúvanie rozprávania v 3. osobe), v cykle Pán vzduchu a král'ov syn o lineárnosti a kauzálnosti nemôžeme ani hovorit'. Ak v predchádzajúcich novelách možno hovorit' o náznaku porušovania textovej ucelenosti, v druhom cykle Hroncových próz ide o ich d’alšie rozrôzňovanie a rozvetvovanie naratívnych pásem. Jednotný autor a narátor je v Pánovi vzduchu... maximálne spochybnený symbolickým gestom jeho multiplikovania sa do rôznych postáv-rozprávačov, epický svet dotvárajú rozličné zdroje dokumentárneho a fiktívneho pôvodu, odbočky transsemiotického charakteru. Epické útvary Pána vzduchu... nemajú vopred určený program, respektíve poetiku, nepočítajúc všeobecné zastrešenie pojmom postmodernizmus, ani jednotnú metódu. Každá poviedka je subžánrom osebe, ale zároveň súčastou vyššieho celku, ktorý je na základe existujúcich literárnoteoretických poznatkov t’ažko jednotne typologicky určit'. Ak hovoríme o poviedkach, potom v zmysle ,prezlečených za poviedky“, ak o novelách tak tiež v zmysle 
„kostýmu“ (Marčok). Uvedené platí aj pri analýze ich vzájomnej významovej prepojenosti, ktorou sa podiel'ajú na vyššom žánrovom útvare. Pán vzduchu ... je heterotematický a hybridný žánrový útvar, $\mathrm{v}$ ktorom sa každý z útvarov diškurzívne rozbieha vo viacerých (syntaktických a sémantických) smeroch. $Z$ uvedeného poetického rozbiehania a rozrušovania rozprávania stálymi vsuvkami vyplýva zdanlivá menšia noetická súdržnost', zretel'nejšia samostatnost' textov a paradoxne ich žánrová „zaokrúhlenost'“. Híbka noetických a významových súvislostí každej prózy sa začína zviditel'ňovat' vo významovej súhre s noetikou d’alšieho útvaru toho istého cyklu, na pozadí súvislostí s predchádzajúcim cyklom próz V. Hronca Prievan (1976) ako aj po prečítaní jeho románu Plný ponor (1999). Tieto vzt’ahy dodatočne re/konštruuje denník o próze vydaný Hroncom v roku 2001 (Algol, čast' pomenovaná Alchýmia fiktívneho). Pre permanentnú žánrovú nestabilnost', „dvojdomost'“, či rozvetvenost' pri genologickom opise a pomenúvaní útvarov knihy Pán vzduchu a král’ov syn budeme používat' úvodzovky.

Pri analýze textotvorných a žánrotvorných elementov uvedenej knižky do pozornosti sa vnucuje hypercitátovost'. Miroslav Dudok vo svojich Poznámkach na text postmodernej prózy (1998) upozornil, že sa v Hroncovej knihe Pán vzduchu a králov syn otázka intertextovosti zauzlila, najmä uplatňovaním poetiky citátovosti, aká nemá obmenu vari v slovenskej tradícii vôbec (Dudok, 1998, 69). Identifikovaniu citačných vzt’ahov v tomto diele pristúpili sme konzultujúc dva zdroje poznámok Vít’azoslava Hronca: na konci knihy Amarna 1 a poznámok Vladimíra Lutrova Alchýmia fiktívneho v knižke Algol (Hronec, 2001A), brali sme do úvahy d'alšie dva prozaické cykly (Prievan, Plný ponor) ako aj zbierku poézie Prázdna streda (2001) Vít’azoslava Hronca. Analýzu citačných vzt’ahov preto realizujeme tak, že ich roztriedime do niekol'kých všobecných typológií, lebo taký rozsah intertextuality, akým je vyplnená druhá kniha próz V. Hronca, by sme $v$ úplnosti v rámci tejto práce nemohli predostriet'. Pred uvedením jednotlivých typológií považujeme za dôležité zdôraznit', že všetky typy Hroncových citátov sú autoreferenčné, funkčne orientované na text, takže pri analýze intertextuality budeme dôraz dávat' na dialogické, respektíve polemické vzt'ahy $\mathrm{k}$ východiskovému textu so zretel'om na ich funkčné pôsobenie. Pri citačnom diálogu, hovorí D. Oraićová Tolićová, vlastný text pocit’uje citát ako neutrálnu zónu, v ktorej je možné realizovat' slobodný medzikultúrny dialóg podla princípu intertextuálneho vzájomného rešpektu (Oraić Tolić, 1990, 40). Pri určovaní typologických skupín nevypustíme zo zretel'a fakt, že typológie sú celok, ktorý reprezentuje množstvo častí vtkaných do celej plochy textu, z ktorého budeme volit' tie, pre význam najdôležitejšie. Citáty v Pánovi vzduchu... sú textotvornými, štylistickými, semiologickými a metatextovými zložkami a dialógy s podtextami a prototextami sa rozbiehajú do niekol'kých historických období, oblastí poznania, vedy a umenia. Tie vzt’ahy sú prejavom onoho, čo R. Barthes teoreticky tvrdil o texte ako o multidimenzionálnom priestore, $\mathrm{v}$ ktorom sa písanie rôzni, utráca pôvodnost', mieša s inými a zráža, o texte ako tkanive citátov, odvodených z nespočetného 
množstva kultúrnych stredísk, ale aj viac, prejavom ontotvornej vlastnosti takýchto vzt’ahov, z ktorých sa v konečnom dôsledku rodia nové (fiktívne) svety.

Väčšina citátov v knihe Pán vzduchu a králov syn sú pravé citáty, majúce presné údaje o prototexte, ktoré sa najčastejšie uvádzajú $\mathrm{v}$ jednom $\mathrm{z}$ poznámkových aparátov. Pravé citáty s úplnými údajmi o citovanom prototexte sú základným príznakom vedeckého citovania a navonok sú referenčné (odkaz na podtext a prototext). Dokonca, jeden typ citátov, transsemiotické citáty, majú v prototextoch vedecké spisy (napr. encyklopédiu fyziky), čo dovedna ukazuje na svojráznu „scientifikáciu“" prózy, ale aj poézie Vít’azoslava Hronca, najmä v prípade poslednej zbierky Prázdna streda. Uvedené skríženie vedy a prózy/poézie u Hronca súvisí s racionalistickým svetonázorom, ktorý spočíva, medzi iným aj v zapájaní sa do všeobecných civilizačných tokov, ktorých súčastou, najmä v 20. storočí, sú vedecké teórie a poznatky. Takže referenčnost' citátov v Hroncovej próze je iba zdanlivá. V nej sa veda, ako súčast' kultúrnej a poznávacej encyklopédie autora, stala dôležitým, ak nie aj rozhodujúcim zdrojom ontologických a semiotických procesov.

Okrem pravých citátov vel'kú čast' Hroncovho diela tvoria - skryté citáty (bez odkazov v poznámkových aparátoch), ktoré sa dajú identifikovat' po prečítaní celého diela, vrátane poézie Vít’azoslava Hronca. Túto skupinu citátov tvoria prevažne autocitáty, motívy, symboly alebo úseky, ktoré autor utvoril v predošlých textoch a potom $\mathrm{v}$ podobe citačného echa, respektíve ,autoecha“ zarad'oval do d’alších, následne uverejnených $\mathrm{v}$ časopsioch a knihách.

Vzhl'adom na druh podtextu, z ktorého sa tak pravé, ako aj skryté citáty čerpajú, v Hroncovej próze nachádzame všetky typy, ktoré vyčleňuje Dubravka Oraićová Tolićová v knihe Teorija citatnosti (1990). Prvým typom sú interliterárne, ktoré pôvodia $\mathrm{v}$ texte iného literárneho diela (napr. epigrafy $\mathrm{k}$ zbierke $\mathrm{z}$ diel Hermanna Brocha a Itala Calvina; „A ked’ kráčame po vode...“ (Hronec, 2000, 106) sú verše z básne Ostrovy srbského básnika Jovana Hristića (1933-2002); „Odyseus sa vrátil domov“ (Hronec, 2000, 106) je hrdina Homérovej Odysey; citát o Sibyle z románu Satirikon Gaia Petronia Arbitra, z Pustatiny T. S. Eliota atd'.). Tieto citáty môžeme vnímat' ako ukazovatele nových semiotických procesov ako výsledka nekonečnej semiotizácie (napr. Pustatina T. S. Eliota zaradená do knižky Pán vzduchu a králov syn). Druhým typom sú autocitáty, medzi ktoré patrí i názov časti „poviedky“ Noc na tretom poschodí: Návrat do Téb roku 1961 nášho letopočtu, ktorý je neúplným citátom (parafrázou) názvu básne Alexander $v$ Tébach v roku 335 pred naším letopočtom, čím autor poukazuje na spoločný motivický a noetický priestor básne a prózy. Poukazuje na novú (de)sémantizáciu motívov, ktoré sa nastolujú v jednom a dotvárajú v druhom texte. Dalším autocitátom sú verše básne Andreja Lutrova („Búrky temný príval“), ktoré sa citujú v ,poviedke“ Noc na tret’om poschodí, a vôbec autocitátmi možno považovat' alúzie na príbehy a motívy v ostatných prózach. Indikatívnym príkladom tomu je „,poviedka“ So širokými nechtami, zaradená do druhého vydania cyklu Pán vzduchu a králov syn (Amarna 1) práve z dôvodov vysvetlenia niektorých postupov 
Vlada a Milana zachytených v predchádzajúcich prózach. ${ }^{2}$ Ďalší typ sú metacitáty, ktorými sa v texte sprístupňujú niektoré poetologické princípy dekonštruktivizmu a semiológie, sem patrí parafráza citátu z knihy Trattato di semiotica generale (1975), uvedená podla textu Ihaba Hassana: Kultura, indeterminacija i imaginacija: margine (postmodernog) doba, uverejnenom v časopise Republika v roku 1985, tieto citáty komentujú formu a výraz Pána vzduchu..., časti poviedky Materiál o motýl'ovi možno vnímat' ako autocitáty, ktoré sú zároveň metacitátmi, lebo sa nimi zdôvodňuje a vysvetl'uje vznik vlastných poviedok a jednotlivých príbehov. Osobitne ako metacitát môžeme vyčlenit' časti textu z knihy Charlesa Jencksa Jezik postmoderne arhitekture (1985), ktorá má i metatextovú ale i intersemiotickú funkciu. Aj ked' sme mali dilemu, či uvedené nezaradit' len medzi intersemiotické citáty, rozhodli sme sa pre skupinu metacitátov vzhl'adom na ich funkciu v texte ,poviedky“ (,,poviedok“"). ${ }^{3}$ Aj ked’ citáty de facto vysvetl'ujú vzt’ah medzi architektúrou a literárnym umením obdobia postmoderny, ich funkcia je teoreticky podložit' dekonštruktivistickú epistému v diele, teda vystupujú ako metacitáty.

Textotvorbu a naráciu tretieho cyklu rozrôzňujú intersemiotické citáty, ktorých podtexty sú umiestnené do iných umeleckých medií: kniha Pán vzduchu a králov syn obsahuje dve detské kresby (Moja mama na bicigli (v texte je autorom Igor Pálik, v skutočnosti ju nakreslila Zuzana Týrová, a kresba budovy s troma poschodiami, ktorú v skutočnosti nakreslila Olena Vinkovičová), kresbu obludy prebratú z knihy Vile $i$ vilenjaci, výstrižok fotografie nahej ženy z časopisu Start, na ktorej sú zapísané prvé verše básne Andreja Lutrova Búrky temný privval, fotografia budovy, v ktorej sa narodil Igor Pálik, v skutočnosti fotografia budovy na Námestí Ferenca Féhera v Novom Sade, výstrižok z novín Politika, na ktorých je odkaz Milana Lutrova svoje priatel'ke Ane, dva výstrižky z mapy: Novi Sad, Turistički plan grada a Barcelona turistica, ktoré znázorňujú časti miest, ktoré sa v „poviedke“ uvádzajú. Intersemiotické citáty sa podielajú tak vo výstavbe Hroncovho časopriestoru, ako aj v procese hybridizácie prozaického žánru. Ich metatextová funkcia spočíva $v$ realizácii techniky koláže, repektíve montáže rozličných textov, ktoré plynú „hlavným“ myšlienkovým tokom postmodernistického diela a poukazujú tiež, že inšpirácia väzí všade a vo všetkom, v najbanálnejších veciach každodennosti, ktoré dokážu ovplyvnit' myšlienkový prúd subjektu. Samotný subjekt sa ich pokúša zmocnit' v snahe o revalorizáciu sveta spejúceho k entropickému zániku, čím je i jeho snaha poznačená protichodným procesom zjednocovania/rozrušovania.

\footnotetext{
Poviedka So širokými nechtami bola prvýkrát uverejnená v Slovenských pohladoch roku 1992, vnikala počas písania tretieho cyklu Plný ponor, dokončená bola v septembri 1991, ako zaznamenáva autor v denníku o tomto cykle (2001A, s. 16). Pôvodne mala byt' zaradená do Prievanu, repektíve Skleného vetra ale pre postmodernistickú povahu textu autor sa rozhodol zaradit' do Amarny 1, do cyklu Pán vzduchu a králov syn.

3 Najviac sa cituje v poviedke Noc na tret’om poschodi ale ako metacitát ho možno brat' na ploche celého cyklu Pán vzduchu a králov syn.
} 
Ďalšiu vel'kú skupinu citátov tvoria transsemiotické citáty, a to interverbálne citáty (zdroje sú neumelecké vedecké texty a novinové články), medzi ktoré patria citáty z Malej encyklopédie fyziky, „Boltzmanova definícia entropie“ podla rakúskeho fyzika Ludwiga Boltzmana, „Clausius-Thomsonova druhá veta termodynamiky" podla nemeckého fyzika Rudolfa Emanuela Clausiusa a anglického fyzika Josepha Thomsona atd'. Uvedené mimoestetické citáty budeme vnímat' v súvislosti s vyššie uvedenou ,scientifikáciou“ prózy, ktorá sa prejavuje v snahe autora a narátora Vladimíra Lutrova racionálne uchopit' podstatu tvorivého procesu ako odrazu vzniku/tvorby univerza.

Dôležitú skupinu citátov tvoria mimoestetické tzv. faktocitáty, respektíve „citáty života“, ktorých je u Hronca nespočetne. Pri faktocitátoch v rovine intertextuálneho výrazu ide o autorovu hru na mimetizmus. Oporu všetkých príbehov, ktoré Vlado podáva alebo opisuje Hronec našiel v skutočnosti. Faktocitáty sú rozmiestnené všade, v každej zložke imaginárneho sveta, v každej „,poviedke“ sa uvádzajú určité skutočnostné reálie, ktoré sa pohybujú od geografických faktov po také detaily, akým je napr. signatúra listov J. Podhradského v knižnici Matice srbskej v Novom Sade, Zmajova ulica, novosadské sídlisko Telep, ulica Ivana Gorana Kovačića na novosadskom sídlisku Telep, Gajova 18 v Novom Sade, kaviareň Biser na začiatku Ticanovej ulice na Telepe, kaviareň Pilot na sídlisku Detelinara v Novom Sade, Nový život, literárny časopis, Michal Babinka pochovaný na novosadskom cintoríne (v súčasnosti sú telesné pozostatky premiestnené do Padiny-poznámka mašs), Mitar Milošević, ktorý sa viackrát uvádza pod pseudonymom Frederik Ešton (Mitar Milošević totiž nedovolil, aby mu meno Hronec zaradil do prózy) atd'. V týchto citátoch próza Vít’azoslava Hronca neustále balansuje medzi bezbrehou fikciou a oporou v skutočnosti, túžiac prekročit' hranicu literáneho umenia a stat' sa životom. Na druhej strane sú miesta v próze, $\mathrm{v}$ ktorých sa explicitne naznačuje, že svet prózy je „svetom osebe“ (Materiál o motýlovi). Hroncova realita nie je d'aleko od historickej skutočnosti, ale obsahuje podstatné zložky (zmenené mená niektorým postavám s prototypom v skutočnosti, domyslené udalosti a p.), ktorými sa od nej odlišuje, čo jej zaručuje samostatnost' a nezávislost'. Podstatnú zložku nezávisloti naplňajú paracitáty (fiktívne) citáty, nemajúce skutočný, ale fiktívny originál. Začnúc poviedkou Muž kráčajúci po vode, paracitáty najprv predstavujú Martinove zápisy do notesa, ktoré Vlado cituje v origináli (v šifrovanej forme $v$ akej ich nechal Martin, čo je vyznačené špeciálnym grafickým písmom) ale uvádza ich aj v preklade, ktorý urobil on sám, $\mathrm{z}$ tej pozície zápisy predstavujú jeden z metatextov prózy. Zápisy Martina Javorníka sa „citujúu na niekol'kých miestach prózy a odd’al'ujú postavu od jej reálneho prototypu. Príkladom paracitátov je fiktívny denník Vlada Lutrova, ktorý predstavuje d’alší metatext, materál, ktorý činí súčast' poviedky. Paracitáty a metatexty sú Martinove Javorníkove listy, z ktorých zist'ujeme, kedy Vlado začína písat' uvedenú poviedku. Tu tiež vychádza najavo údaj dôležitý pre konzistentnost' celého fiktívneho sveta rodiny a tým je, že Vladimír Lutrov napísal cyklus Prievan. Vladimír Lutrov sa teda v poviedke Muž kráčajúci po vode zviditel’ňuje ako 
podstatné spojivo sveta Hroncovej prózy, čo sa potvrdí aj v d’alších „poviedkach“ cyklu Pán vzduchu a králov syn a predstaví ho v nezávislom svetle od skutočného autora V. Hronca. V „poviedke“ So širokými nechtami sa uvádza, že Vladov príbeh a jeho snaha o písanie o vlastnej rodine majú vysoký potenciál byt' témou vyššej formy, ktorá nadrastá hranice jednotlivých prozaických kníh. Pripomíname, že „poviedka“ je dopísaná na margo všetkého dovtedy napísaného a predstavuje, podla Hroncových slov, „ohnivko, ktoré chýba“. Popri uvedených paracitátoch, d’alšie fiktívne metatexty sú román Frederika Eštona Lun protiv Hekate, Vladove prepisy magnetofónových záznamov rozhovorov s Milanom Lutrovým a Elou Lutrovovou, list Miša Lutrova Jule Pagáčovej v poviedke Noc na tret’om poschodí, list Alberta Einsteina z roku 1900, ktorý je citátom citátu (citátom v článku Pavla Simića o listoch Alberta Einsteina Mileve Marićovej, uverejnenom v Politike 4. mája 1987) atd’. Ako uvidíme neskôr, práve „citát citátu“ zohrá dôležitú významovú úlohu v pochopení hlavného problému Igora Pálika (oidipovský komplex) v poviedke Noc na tretom poschodí, čo napovedá, že autor, uplatňujúc pricíp dekonštrukcie, do tých najohl'ahlejších častí príbehu vsadil uzlové významy nielen „poviedky“, ale aj prozaického celku.

Text $\mathrm{s}$ jeho nespočetnými meandrami $\mathrm{v}$ citátoch odzrkadl'uje postmodernú teóriu o maximálne „rozdrobenom“ časopriestore, z ktorého sa, súc podla predošlého príkladu, dá konštutovat' celok tak v zmysle významu, ako aj na úrovni metakomunikácie s problematikou žánru.

V novele Amarna zjavuje sa d’alší typ vakantných (prázdnych) citátov bez skutočného východiska (podtextu/prototextu), ktoré reprezentujú fiktívna Teória gravitácie Marijana Juričevića, z ktorej Vlado „cituje“ úryvky, potom paracitát o živote Alexandra Macedónskeho a d’alšie „epištoly“, fiktívne listy, v ktorých sa vysvetl'ujú „osudové“ spojivá medzi predmetmi a udalost'ami. Ich ciel’om je zosmiešnit' l'udskú potrebu po jednotnom zdroji, ktorý všetko determinuje (všetky „determinanty“ v diele sú výmysel jedného človeka). Je to ilustrácia idey o entropii súčasného sveta, ktorý nemožno obsiahnut' jednotnou teóriou všetkého, entropii, ktorá sa prejavuje v chaotickom, dezintegrovanom a dezintegrujúcom prúdení množstva rozličných zložiek, ako obraz novodobej pustatiny, ktorej začiatky a predtuchu jej trvania podal Hroncov predchodca T. S. Eliot.

V znamení dekonštrukcie epického priestoru, tým aj narúšania stabilných hraníc žánru poviedky sa ako signifikatná prejavuje próza Noc na tretom poschodí. Príbeh rámcuje vidina jednej z postáv (Miloš Heraković), na základe ktorej druhá postava, jeho neskorší spolubývajúci Igor Pálik, jeden z aktérov Herakovićovej vidiny, vyrozpráva príbeh celej prózy. Narátorovi Igorovi príbeh pridelí jeho otec Vladimír Lutrov, ktorý je domnelým autorom aj tejto prózy. Podanie z perspektívy vidiny automaticky spochybňuje pravdivost' obsahu a posúva príbeh do nadskutočna, to jest do pomyselného sveta podávatel'a (ako v novele Kl'úč v prozaickom cykle Prievan). V Mužovi kráčajúcom po vode autor rezignoval na pravdu, tu si na ňu od začiatku ani nenárokuje. Príbeh je aj tu roztrieštený na množstvo 
simultánne plynúcich, štýlovo a žánrovo odlišných textov, ktoré sa podávajú z viacerých uhlov (perspektív viacerých rozprávačov, ktorý sa zjavujú v citátoch). Plynutie rozličných textov v rámci väčšieho celku (prózy Noc na tret’om poschodí) je graficky znázornené členením na lavý a pravý stĺpec, pričom rovnoprávnu účast' v tvarovaní textu majú aj intersemiotické a transsemiotické citáty: vyššie spomenuté mapy, dva detské výkresy, výstrižok z novín s rukou dopísaným obsahom-básňou Andreja Lutrova, kresba a fotografia. Próza je z aspektu textotvorných, naratívnych a štylistických postupov heterogénna a polyvalentná, zo žánrového aspektu hybridná. V osemdesiatych rokoch 20 . storočia preto pôsobila inovačne a pre mnohých „nečitatel'ne“ a „experimentálne“. Heterogénnost' Noci na tret’om poschodí ilustruje postmoderný disperzívny stav t’ažko odhalitel'ného dostredivého bodu, všetko, čo sa mihne subjektovým vedomím sa môže dostat' do prózy, preniká bez jeho vedomia, ako skutočnost' večného pretlaku textov.

Predsa však, podobne ako v predchádzajúcej próze Vít’azoslava Hronca, jednotlivé útržky rozličných textov nadobúdajú funkciu znaku, ktorého súvislosti možno mapovat' smerom k centrálnemu znaku, to jest $\mathrm{k}$ téme prózy, ktorou je počatie seba samého (Igor Pálik sa z roku 1982 transponuje do roku 1962, stretne sa s vlastnou matkou, ktorú $\mathrm{v}$ živote nikdy pred tým nespoznal ani na fotografii, vyspí sa s ňou a počne seba). Ked' znakovost' tohto motívu vnímame v súradniciach postmodernej epistémy, ide o metaforu ,počatia príbehu v sebe samom“, to jest o zrod literárneho diela bez demiurgickej funkcie tvorcu. Uvedená dekonštrukcia (autora) má aj hodnotiaci aspekt, respektíve ,počatie seba samého“ možno vnímat' ako iróniou prehnaného antropocentrizmu súčasného človeka, ktorý vo všetkom dianí/počínaní „rozumie“ jediného človeka/subjekta ako autora (textu), repektíve tvorcu: Boha/vedca. V tomto zložitom súzvuku niekol'kých významových hladín, próza svojrázne a originálne, balansujúc na hranici fantastiky a skutočnosti, ironizuje úlohu autorstva/tvorcu/subjektu v objasňovaní sveta. Takto vlastne téma predstavuje jediný „faktor stability“ a dostredivý bod pri definovaní žánru poviedky. Poetikou intertextuality a jej významom centrálna téma zároveň spochybňuje akúkol'vek jednotnost'. Vznik textu zo „seba samého“ demonštrujú padajúce, prebiehajúce texty rôznych žánrových útvarov ako aj kresby a mapy. Takže, hypertrofia textov rozbíja ideu o ucelenosti príbehu, pritakávajúc postmodernistickú ideu spochybnenia autora. Týmto sa potvrdzujú aporické dôsledky žánrového definovania ,poviedky“.

Lenže v prípade „poviedky“ Noc na tretom poschodí a na jej príbeh počatia seba samého sa musíme dívat' z uhla Vladimíra Lutrova, ktorý seba samého štylizoval do pozície Igora Palíka. „Prevteliac sa“ do roly a perspektívy svojho nemanželského syna, Vladimír Lutrov zazátvorkovane prehovoril znovu o vlastnom oidipovskom komplexe. Tak sa do fókusu témy tak Noci na tret’om poschodí, ale aj prózy ako celku, dostáva problém primárneho vztahu: syna a matky a otca a syna, ktoré V. Hronec nastol'uje tak vbásnickom diele neskorého modernizmu (Hranica) ako aj v hyperrealistickom románe Plný ponor. Archetypálne situácie a mýty podliehajú novej dekonštrukcii v polytematickom diele Pán vzduchu a králov 
syn a zároveň „otvárajứ uvedenú „,poviedku“ smerom nielen k vyššiemu žánrovému celku knižky, ale aj k iným žánrovým a druhovým útvarom V. Hronca. „Poviedka“ Noc na tret'om poschodí sa roztvára voči neredukovatel'nej zložitosti vedomia o celkovom diele V. Hronca.

Žánrovo teda uvedený prozaický útvar, podobne ako predchádzajúce útvary spomenutej knižky V. Hronca Pán vzduchu a králov syn, možno definovat' ako samostatnú ,ppoviedku“ (pre relatívne jednotný tematický rámec a časopriestorové určenie). Na druhej strane je to významovo neuzavretý útvar, lebo sa totiž nedozvedáme hlbšie o zmysle Igorovho zápasu s oidipovým komplexom. Dozvedáme sa však o zázračnej moci onej básne Andreja Lutrova, ktorú písal v prvej „poviedke“ prozaického cyklu a ktorá Igorovi, (ked' ju napokon pred študentskou reštauráciou zopakuje v originálnom tvare) umožní prevtelenie do druhého času („omladnutie“ po počatie seba samého), ako aj náznak zložitého vzt’ahu otec-syn. Na jednej strane je to ucelený žánrový útvar atomizovanej štruktúry, montážou pravých a aluzívnych citátov, ${ }^{4}$ ktorý na druhej strane významovo súvisí s inými prózami. Súvisí ale i s celkovým postmodernistickým ladením textov V. Hronca, voči ktorým znamená jeden z možných vstupov.

Iný prípad žánrovej „dvojdomosti“ predstavuje „,novela“ Amarna, záverečná próza knihy Pán vzduchu a králov syn. Podla tejto prózy pomenoval Hronec druhý a tretí zväzok výberu z diela (Amarna 1, Amarna 2), čo napovedá, že do nej umiestnil potenciálne najdôležitejšie motívy pre tematickú súdržnost' prozaického sveta. Už Michal Harpáň v Premenách rozprávania (1990) charakterizoval Amar$n u$ ako novelu, pre širšie poetologické a noetické stvárnenie. No podobne ako pri predchádzajúcich Hroncových prózach, pre intertextualitu, ktorá sa prejavuje cez množstvo citátov, aj Amarnu možno zatriedit' do skupiny noviel iba podmienečne.

Amarna sa začína snom Vlada Lutrova v chate Vezirac v roku 1962, na ktorú chodí d'alších desat' rokov s ciel'om aby sa mu znovu prisnil ten istý sen, čo sa aj stane v roku 1972. V prvom sne sa Vlado pokúša identifikovat' svojho protihráča v hre šachu a rozlúštit' význam sna. Sen tvorí vstupnú, ale nie aj jedinú symbolickú hladinu komplexnej Amarny. Hlavný príbeh „,novely“ diktuje druhý sen, v ktorom Vlado na Gajovej 18 sníva seba ako Jozefa Podhradského, čo zapríčiní jeho pátranie po životopisných údajoch o tejto historickej postave. Táto snaha zavedie ho však k rukopisu o novej teórii gravitácie fyzika Marijana Juričevića, ktorého manželka Elza (v Amarne babka na smrtel'nej posteli) bola milenkou jeho dávno zosnulého (vskutku zavraždeného) príbuzného Milana Lutrova, ale aj gazdinou Vladimírovho bratranca Milana Lutrova. Pátranie po Marjanových údajoch a d’alších rukopisoch zavedie Vlada k Elze Juričevićovej, prostredníctvom ktorej sa znovu dostane k príbehom o svojej rodine, rezignujúc na odkazy snov. Široký

$4 \quad$ Napríklad podnázov Ospalý drak sa díva zo strechy je alúzia na dielo Charlesa Jencksa preložené do srbčiny ako Jezik postmoderne arhitekture, ktorý strechu budovy Casa Batlló v Barcelone prirovnal k ospalému drakovi, príšera A Bao A Qu je citát z Borgesovej knihy Príručka fantastickej zoológie, podnázov Hmotný bod a vlnový dej je citát z teoretického referátu O teórii zákona rozmiestnenia energie v normálnom spektre... Maxa Plancka atd'. 
tematický oblúk má bohatú symbolickú náplň, v ktorej sa rovnocenne podielajú obsahy snov, mýty a citáty literárnych diel, ktoré vyust'ujú znova k rodine a ich príbehom, o ktorých píše racionálny a vedecky podkutý Vladimír Lutrov.

Leitmotívom „novely“ je „idea o rozrušovaní priestoru hmotou“, respektíve idea o „roztrieštenosti a indeterminovanosti postmoderného myslenia a cítenia“ (Hronec, 2001A, 205-206). Tematický plán sprevádza do dôsledkov poetika roztrieštenosti, ktorú spôsobuje intertextualita. $V$ textotvorbe sa podiel'ajú pravé, paracitáty, trassemiotické citáty (fingovaný denník Andreja Lutrova, citát z jeho meditatívnych próz, ,záverečná legenda z knihy Andreja Lutrova Zrkadlá Achetatonu, 1969, s. 127-128“, odvádzajúce semilogické procesy do iných kultúrnocivilizačných polôh; denník Vladimíra Lutrova, imaginárne listy Elzy Juričević Ele Lutrovovej a potom citáty z prvého antického románu Petronia Gaia Arbitera, Románu o jednom bohovi M. Druona, citát z listu A. Einsteina Mileve Marićovej - podl’a článku D. Simića Pisma Milevi Marić, Politika, 4.5. 1987, s. 13 -, citáty z Malej encyklopédie fyziky, citát názvu zbierky básní Anice Savić-Rebac Večeri pri mori). Strieda sa viac uhlov nazerania, viac rozprávačov, o čom už kritika písala. Striedanie a navrstvovanie segmentov rozličných výpovedí a časových pásem ku koncu ,novely“ prebieha z riadku do riadku, intenzifikuje sa, pričom sa získava dojem, že zastupujú stav vedomia pred vyvrcholením hraničnej životnej situácie, respektíve stavu urýchlenej mozgovej aktivity pred smrtou. Zároveň, čoraz intenzívnejšie rozbiehanie úlomkov vel'kého počtu informácií v súlade so semiotizáciou ,vedeckých“ citátov, nechávajú dojem oslobádzania obrovskej energie, akoby stav pred explóziou a definitívnym roztrieštením. Takáto nekonečná „expandnost” textu“ (Marčok, 2010), ktorej jediným východiskom sa zdá explózia všetkého je zasa postmoderným gestom, v podtexte ktorej možno identifikovat' teóriu o Vel'kom tresku. Z množstva informácií (ktorých rozsah len môžeme tušit') čitatel' vníma iba úlomky, zdrapy a fragmenty, lebo v ich rýchlosti a expandnosti zachytáva iba nepatrné detaily, uvedomujúc si závratnú hĺbku vlastnej bezradnosti, malosti a dočasnosti. Milióny fragmentov tvoriacich skutočnost' "novely“ pripomínajú situáciu chaosu po Vel'kom tresku, zároveň však ukazujú, že sa vesmír svojím entropickým rozkladom urýchlene približuje k novému Big bangu, k znovuzrodeniu univerza zo zdrapov seba samého. Náš univerzum, ktorý pozostáva z narastajúceho množstva schaotizovaných informácií, je na jednej strane univerzom spomienok (na jednotu, Big Bang), respektíve, ako sa to od čias Borgesa uvádza, univerzom záznamov o Vel'kom tresku, ale aj nekonečnou rýchlost'ou sa blížiaci k novej explózii, ktorá má potenciál utvorit' d’alší svet z pozostalých fragmentov starého. Novela, repektíve „novela“ v najširších významových rámcoch zohl'adňuje ,filozofiu“ celej Hroncovej prozaickej trilógie. Predstavuje zároveň uzol pre mnohé diskurzívne línie na celej čiare Hroncovho prozaického sveta. Ani v tomto „filozoficko-vedeckom“ rámci sa intertextuálne väzby Amarny nevyčerpávajú.

Jedným z najinteresantnejších citátov v „novele“ Amarna je báseň Model prerušovanej rovnováhy, ktorú vnímame ako citát predovšetkým preto, že ju „,napísal" Vladimír Lutrov a ktorá bola prvýkrát uverejnená v decembri 1988 v Novom 
živote (pod Hroncovým menom, neskoršie pod Vladovým), niekol'ko mesiacov pred prvým uverejnením Amarny (máj-jún (1. čast'), jún-júl (2. čast') 1989 ) tiež v Novom živote. V básni, neskôr uverejnenej v zbierke Prázdna streda, sa kladie otázka „Ako stvorit’ hocičo / Pomocou jeho dekonštrukcie?“ (Hronec, 2001, 38). $\mathrm{V}$ Amarne sa podáva opis procesu dekonštrukcie:

Vtedy sa tie pravidelné transparentné kvádre začali štvrtit' a lámat', ten vel'ký celistvý priestor sa najprv rozčesol na dve časti a potom, neskoršie, ked'spomienka na Ivanu postupne začala zanikat' tam kdesi v híbke, za súhvezdím Ariesa, začal sa rozdrobovat' a trieštit' na vždy menšie kúsky, ktoré sa postupne vzd'al'ovali od seba...“ (2000, 176), „až priestor okolo nás sa (presne podl'a Juričevićovej teórie) začína trieštit’ a rozdrobovat', najprv na väčšie, potom na čoraz menšie priesvitné romboidové kryštály, svojím d'alšim rozkladom sledujúce každý jej posunok..." (s. 179).

Báseň síce možno chápat' ako metatext, ale nie aj ako úvod do dekonštruktivizmu, ${ }^{5}$ lebo ešte pred jej uverejnením Hronec mal napísané predošlé dekonštruktivistické poviedky. Funkciu básne vidíme v komentovaní prózy, ako ukazovatel'a procesu vzniku básní na pozadí prózy, t. j. vzniku básne Model prerušovanej rovnováhy na pozadí predošlých ,poviedok“ Pána vzduchu a královho syna. V texte Amarny, parafrázujúc text básne Model prerušovanej rovnováhy, sa prvýkrát poukazuje na súvislost' básní a prózy, čo potvrdzujú autocitáty v básňach Prázdnej stredy vzniklé na pozadí textov Amarny. V Amarne je množstvo situácií, ktoré sa citujú v básňach umiestnených do poslednej zbierky básní Prázdna stre$d a$. Nepriame odkazy na básnický svet nachádzame najprv v mýte o Orfeovi, „básnický“ mýtus zaradený je do časti Kúskovanie Oiagrovho syna. Lenže tento mýtus je podtetxom jedného z postulátov postmodernizmu (podla Ihaba Hassana), takže nie je reprezentatívnym ukazovatel'om medzitextového nadväzovania prózy a poézie. V Amarne sa finguje citát z románu Maurica Druona o živote Alexandra Macedónskeho (s. 182-183). Pravý citát z románu je súčastou intertextuálnych vzt’ahov Hranice, presnejšie básne Medzi dvoma ohňami II., ${ }^{6}$ ale aj básne Teória veštby v zbierke Prázdna streda, na čo Hronec poukazuje v poznámkach o Amarne (Hronec, 2000A1, 245). Dalej, citáty v básňach a v Amarne, ktoré majú podtext vo fyzike (básne Spomínam si na Penziasa a Wilsona, Spomínam si na Nielsa Bohra, Žiarenie čierneho telesa etc.) v Amarne citáty („Boltzmannova definícia entropie“ (s. 177, 244), „o Clausius-Thomsonovej druhej vete termodynamiky“ (s. 178, 244) atd'.) poukazujú na podobný žáner podtextu poézie a prózy. Verše v básni Navzájom a osve „Ked’ moje telo vystrieda / Prázdny priestor / Čistejši od čohokol'vek / Na svete" (Hronec, 2001, s. 28, prvé uverejnneie v r. 1988) sú len obmenou názvu siedmej kapitoly pomenovanej Čo bude s priestorom, ktorý zaberám, ked' tu už raz nebudem $(2000 \mathrm{~A} 1,186)$, v ktorej sa rozoberá prúd myšlienok

Ked' ju druhýkrát uverejnil v Novom živote Hronec ako jej autora uviedol Vladimíra Lutrova a k básni uviedol aj poznámku „Pokus o manifest dekonštruktivizmu“, čo už bolo priamou narážkou na súvislosti básne s prózou Amarna, nie však ako jej manifest.

6 Uvádza sa v poznámkovom aparáte (Hronec, 1981, s. 67). 
Marijana Juričevića. Posledná strofa básne Nadarmo sa zobúdzam (prvýkrát uverejnená v roku 1989, vznikala v tom čase ked' aj Amarna) : „Zobúdzam sa v nejakej cudzej izbe / V nejakom cudzom meste / V nejakom cudzom sne“ $(2001,59)$ hovorí o vplyve snov, prostredníctvom ktorých sa subjektu vnucuje vedomie niekoho iného, čo je jedným z centrálnych motívov Amarny, o čom hovorí „Vlado“ v Alchýmii fiktívneho: „Až ked' mi 1. júla 1972 (obmenou sna, na ktorý som celých desat' rokov čakal) vnútila vedomie Jozefa Podhradského (čo ma, prirodzene, vyburcovalo zo sna a úplne vykolajilo)“" (Hronec, 2001A, 205). V Amarne sa uvádza, čo sa stalo potom: „Po prebudeni ma najprv vydesil prudký kontrast medzi nepreniknutel'nou tmou v onej chate pod princovým križom a predstavou širokých jasných priestranstiev čudnej spomienky na život, ktorý celkom zaručene mojim životom nebol““ $(2000,224)$. Medzi básňou a „novelou“ je spoločný motív „existencie v cudzom vedomí“, čo napovedá, že báseň je napísaná na pozadí onoho motívu z Amarny, motívu vnucovania cudzieho vedomia prostredníctvom snov, lebo v básni sa totiž opisuje ,život v nejakej inej dobe“, ktorý je „prebudením v nejakom inom sne“" (2001, s. 59). Môže to znamenat', že subjektom básne je „persóna“ Jozef Podhradský, ale to vskutku pre význam básne nie je dôležité, lebo dôraz je na procese prevtel'ovania sa. Napokon, motív sa dostáva do románu Plný ponor $\mathrm{v}$ podobe autocitátu z denníka V. A. Hronca (Triumvirát), kde sa dozvedáme, že sa takýto sen prvýkrát prisnil Vladovi v roku 1966, ktorý môžeme tlmočit' ako predtuchu onoho sna z roku 1972. Ďalšie medzitextové nadväzovanie medzi Amarnou a poéziou V. Hronca nachádzame pri básni Sloveso predstihnút: obraz „šachovnice bez figúrok“ a niekoho, kto „Neviditel’nými rukami posúva / Nejestvujúce figúrky“" obmieňa sa $\mathrm{v}$,novele“ $\mathrm{v}$ podobe podobného obrazu, ktorý pozoruje prúd vedomia vtŕhajúceho do snov Vladimíra Lutrova: „Premiestňujem sa $k \check{s} a$ chovým figúrkam, v duchu začínam hrat'sám so sebou jednu z tých partií, v ktorej vždy i vyhrávam i prehrávam;"“ (2000, 222), svoj sen Vlado opíše na začiatku Amarny: „Z druhej strany šachovnice, chrbtom k rachotu doliehajúcemu otvoreným oknom a dverami, sedel mladik, ktorého som sice nepoznal, ale z čŕt jeho tváre bolo vidno, že je to Ivanin pribuzny"“ (2000, s. 175), vskutku sníval svojho budúceho syna. Symbol sna v oboch útvaroch zastupuje sféru, do ktorej jedinec nemôže zasiahnut', ktorá však zasahuje jeho sen a jeho život, tým, že mu niektoré veci „prezrádza“. Napovedá to spoločný imaginárny podtext básne a „novely“, svojráznu autorskú filozofiu, ktorú v básňach podáva v podobe „podstát“ a konštánt, zatial' čo $\mathrm{v}$ próze podáva $\mathrm{v}$ podobe príbehu. Sú aj d’alšie symboly, ktoré sa $\mathrm{v}$ básňach a novele citujú zo spoločného imaginárneho podtextu Vít’azoslava Hronca napr. „svietiaca ruka“ uvádza sa aj v poéme Kolesá, hviezdy moje ako aj v básni $S$ konečnou platnostou, niekol'kokrát sa konkrétne spomína v próze:

Ruka, ktorá v popoludñajšich hodinách vo štvrý den̆ po Novom roku 1924, $v$ izbe nad obchodom (tekstilna radnja Marijana J. Juričevića, promovisanog doktora fizike) v Ulici Majke Jevrosime 4 pišse list Elene Losherovej do Petrovca; ruka, ktorá pät dní pred tým istým Novým rokom o štvrtej poobede otvára v tom istom dome dvere na izbe, do ktorej asi hodinu predtým stamodtal'vstúpila dnu 
istá neúprosná, na kost' vychudnutá pani; ruka, ktorú l'ahostajne stískam aj ja sám koncom októbra 1967 [...] ruka, nad ktorou tam, po pätnástich rokoch znova vidím seba, uvzato sliediaceho po súvislostiach, ktoré mi podnes unikajú [...] (2000, 182-185).

Zrejmé je, že ruka je metonymiou autora-spisovatel'a, ktorý je v básni spochybený množstvom otázok, zatial' čo sa $\mathrm{v}$ próze jediné autorstvo spochybňuje opisom množstva „prestupov“ tej istej „ruky“, čo je, mutatis mutandis, význam vplyvu intertextuality na ontológiu literárneho umenia. Uvedené je i podstatou samotného procesu intertextuality v postmodernistickom diele. Dalo by sa hovorit' ešte o d'alších medzitextových nadväznostiach poézie (umiestnenej do zbierky Prázda streda) a prózy Amarna (napr. o vzt’ahu básne Školský priklad alúzie a časti Sny).

Možno teda uzavriet', že uvedené básne V. Hronca sú akoby „podstatami“ vydestilovanými z vymyslených, prepracovaných, či skutočných (nie je podstatné) príbehov Amarny. Ked' sa na uvedené vzt'ahy pozrieme z aspketu celkovej Hroncovej tvorby, všímame si, že tu ide o opačné procesy vzl'adom na obdobie konca šest'desiatych rokov, ked' próza vznikala na pozadí poézie. Vo vzt'ahu k tomuto obdobiu, vznik básní na pozadí prózy, môžeme vnímat' ako ich zrkadlový odraz. Aj v tomto prípade platí charakterizácia básnika ako v období vzniku Prievanu, ktorý nie je lyrik, ale analytik.

Popri tom, že sú všetky „poviedky“, vrátane jednej „novely“, uzavreté štruktúrno-významové celky, viacvrstevná významovost' jednotlivých textových tém, ktoré sa začínajú v jednom a dotvárajú v druhom texte, odhal'ujú nielen vzájomnú súvislost', ale aj logickú usporiadanost' a vysoký stupeň kondeznovanosti štruktúrno-významových zložiek na úrovni knihy ako celku. To hovorí, že Pán vzduchu a králov syn je viac ako cyklus ,poviedok“, je to prepojený systém, ktorý sa čitatel'ovi otvára po odhalení súvislostí medzi zložkami. To potom znamená, že na jednej strane, Pán vzduchu a králov syn funguje ako cyklus samostatných celkov, ale zárove sa hranice týchto „poviedok“ na pozadí sémantiky celku rozpúštajú smerom k väčšiemu prozaickému útvaru. No tento vyšší žánrový útvar zasa len nemôžeme jednoznačne definovat' ako román. Spochybňuje ho rad intertextuálnych vzt’ahov, ktoré formu otvárajú smerom k poézii. Pán vzduchu a králov syn je teda hybridná forma, pozostávajúca zo samostatných častí, majúcich vlastný svet štruktúry a významu, ktorý sa zároveň rozpúšta v prospech spoločného celku pod tlakom ich vzájomnej súčinnosti. Takisto, prepojenie Amarny s básňami Prázdnej stredy napovedá ešte jednu dôležitú vec: hranice žánrov Hroncových diel sa rozplývajú nielen $\mathrm{v}$ smere zjednocovania do celku prózy, ale aj v smere prekračovania hraníc prózy a poézie. Tak je motivická a noetická súdržnost', ako aj súdržnost' v poetike imaginárneho sveta očividná, ale zároveň i spochybnená. Tento genologicky aporický stav spôsobuje intertextualita, ktorá literárne dielo V. Hronca na jednej strane roztvára smerom $\mathrm{k}$ jedinečnému celku, zatial' čo na druhej strane činí množstvom samostatne a nezávisle existujúcich nielen žánrových, ale aj druhových literárnych útvarov.

Kniha Pán vzduchu a králov syn predstavuje paradoxne zaokrúhlený celok, ale i článok v mozaike, ktorú spolu utvárajú tri knihy próz a kompletná poézia 
Vít’azoslava Hronca, vrátane denníkových záznamov Hroncovej postavy Vladimíra Lutrova. Celkové dielo V. Hronca, vrátane toho z obdobia neskorého modernizmu, vd’aka intertextualite a najmä typu autocitátov, definujeme preto podl'a zásad postmodernistickej genologickej teórie. Hroncov postmodernistický literárny útvar Pán vzduchu a králov syn je teda do dôsledkov postmoderný - jeho druhové a žánrové hranice sa rozprúštajú v prospech vyššieho žánru, zatial' čo vyšší žáner existuje iba ako rekonštrukcia vo vedomí čitatela.

\title{
LITERATÚRA
}

Dudok, M. (1998). Úvod do textiky. Báčsky Petrovec: Kultúra.

Hronec, V. (2000). Amarna 1. Beograd, Báčsky Petrovec: Zavod za udžbenike i nastavna sredstva, Kultúra.

Hronec, V. (2001A). Algol. Báčsky Petrovec: Kultúra.

Hronec, V. (2001). Prázdna streda. Nadlak: Ivan Krasko.

Marčok, V. (2010). V poschodovom labyrinte. Bratislava: Literárne informačné centrum.

Oraić Tolić, D. (1990). Teorija citatnosti. Zagreb: Grafički zavod Hrvatske.

Žilka, T. (1995). Text posttext. Nitra: Vysoká škola pedagogická v Nitre.

Hvišč, J. (1990). Žánre v postmodernizme. Slovenská literatúra, 37, 6, 517-525.

Marína Šimáková Speváková

\section{THE PROBLEM OF GENRE CLASSIFICATION OF POSTMODERN PROSE FROM AN INTERTEXTUAL PERSPECTIVE (EXAMPLIFIED THROUGH THE WORKS OF VÍŤAZOSLAV HRONEC)}

\begin{abstract}
SUMMARY
This paper analizes the problem of genre definition of postmodern proze using the example of the proze book The Lord of Air and the King's Son by Vit'azoslav Hronec. Two groups of factors are observed, those that enable genre consistency and those that destabilize it. The main factor of genre destabilization in Hronec's works is intertextuality precisely because it, via the use of selfquotes, creates a consistency. The multifunctionality of intertext in Hronec's work not only dissolves the boundaries of genre but also those of literary types. The book The Lord of Air and the King's Son represents a paradoxically rounded whole but is also a segment of a mozaic made up of three prose books as well as the complete poetry of Vítazoslav Hronec. Included in this are journal entries of Hronec's character Vladimír Lutrov. Due to intertextuality and self-quotation the entire work of V. Hronec, including that of the late modernist period, is defined according to principles of postmodern geneological theory.

Key words: literary genre, genealogy, postmodernism, intertextualiy, citation, story, novel, Vít’azoslav Hronec
\end{abstract}

